\title{
Analysis of Value Added Distribution of Brown Sugar (Saka) Agroindustry in Bukik Batabuah Village Canduang Sub-district Agam Regency
}

\author{
Nadia Firnalista, Nofialdi, and Zednita Azriani
}

Agribusiness Study Program, Faculty of Agriculture, Universitas Andalas, Indonesia

\begin{abstract}
Rural agroindustry can absorb a relatively high labor rate, but the added value of the products is very low, resulting in low labor productivity. This research aims at describing the process of sugarcane into brown sugar and analyzing the added value of brown sugar agroindustry as well as its distribution in Bukik Batabuah Village, Canduang Agam Sub-district. The data were collected from six brown sugar processing home industries. This research found that there were three kinds of brown sugar namely saka kariang, saka gatah kuniang and saka gatah merah, which were only different in the time of cooking, storage process of tengguli, and heating of tengguli on saka gatah processing. These made the three types of brown sugar have different texture, taste, color and price. From their added value, saka kariang and saka gatah kuniang were classified as medium products, while saka gatah merah was classified as a low product. In addition, this research reveals that the smallest added value distribution was received by paid labors. Based on the findings, the following suggestions are recommended: (1) the brown sugar business should focus on developing a business of saka kariang processing; and (2) the added value of brown sugar could be enhanced by the use of effective and efficient production machinery, so that the added value distributed to the brown sugar agroindustry could be improved.
\end{abstract}

Keywords: agroindustry, brown sugar, value added

Received 24 February 2018 | Revised 12 March 2018 | Accepted 23 March 2018

\section{Introduction}

Indonesia is an archipelagic country whose majority people live in rural areas and work in primary sectors, especially agriculture. The characteristic of Indonesia as an agrarian country implies that the agricultural sector has an important role in the development of the national economy [1]. In the framework of agricultural development, agroindustry is a major driver of agricultural development, especially in the future, agriculture will serve as the mainstay sector in national development, resulting in the greater role of agroindustry [2].

Rural agroindustry plays a major role in the absorption of rural labor, but its role is relatively small in the creation of added value which is defined as the difference between the value of output

*Corresponding author at: Agribusiness Study Program, Faculty of Agriculture, Universitas Andalas, Limau Manis 25163, Indonesia

E-mail address: firnalistanadia@gmail.com 
and the value of input, derived from labor and investment or capital contributions. The status of agroindustry laborers in the household handicraft industry (HHI) is mostly unpaid laborers (or family labors). However the consequence is that the family labors do not earn income, and in the HHI output value their payment is called benefits for labors. In 2003 the HHI agroindustry group only gained an added value of 837 percent. It is assumed that the added value of rural agroindustry is mostly wage of the family labors. A relatively high employment absorption and with small added value results in very low labor productivity as well. This indicates that rural agroindustry has not been able to solve rural poverty problems [3].

The amount of added value distribution to labors and other agroindustry actors is influenced by the generated added value. If the generated added value is small, then the added value distribution to the agroindustry will also be small, and vice versa. According to Bunte (2006 in Hidayat et al. [4]), the uneven distribution in the chain of agroindustry activities may endanger its survival and hamper the efforts of modernizing agriculture, hindering the progress of the agroindustry. The result of Bunte's research observes that the share of the laborers' agricultural benefit in Europe is getting smaller when compared to processors (producers), traders, distributors, and food service providers.

The added value depends on the amount of investment and technology used. One of the agricultural products that can add value is sugarcane. Sugarcane is a plantation commodity that has good prospects to be developed commercially. All of its stalk parts (from the upper part to the lower part) contain sugar water with levels reaching 20 percent. Sugar water is very much useful as the raw material of processing sugar and brown sugar [5]. The process of making brown sugar can be done by sugarcane farmers traditionally.

In Agam Regency, the agroindustry of processing brown sugar has widely developed, one of which is in Bukik Batabuah Village, Canduang Sub-district. Bukik Batabuah Village is the largest producer of sugarcane in Canduang Sub-district. In this village, the main livelihood of most of the sugarcane farmers is by processing sugarcane into brown sugar. This brown sugar handicraft industry has been held for generations conducted by sugarcane farmers in Bukik Batabuah Village aiming at adding values to sugarcane. Creation of added value has a very important role in the development of brown sugar home industry in Bukik Batabuah Village. Such added value is expected to increase the income of farmers because of a high selling price difference between brown sugar and sugarcane stalks. In addition, this also aims at creating prosperity for sugar brown agroindustry actors. The existence of brown sugar household handicraft industry has been able to provide an increase in added value to the brown sugar production. Therefore, the development of the brown sugar household handicraft industry will further increase the employment opportunities both in the supply of raw materials, processing and marketing of brown sugar and in the increase of added value, which will ultimately affect the welfare of labors in the agricultural sector. 
A research on the added value distribution to brown sugar agroindustry in Bukik Batabuah Village is important for the rational and balanced added value calculation to the brown sugar agroindustry actors that include labors, farmers as the producers of brown sugar, and other input contributors. By using the analysis, the added value and the income received by the production factor from the activity of creating added value to brown sugar can be obtained.

\section{Method}

This research was conducted in Bukik Batabuah Village, Canduang Sub-district, Agam Regency, West Sumatera, using a case study method by focusing on one case intensively and in detail. The data used in this research were both primary and secondary data. The primary data was obtained through direct field observation and interviews with key informants from 6 units of sugar processing business, meanwhile, the secondary data were obtained from literature and previous studies.

The data were analyzed using a qualitative and quantitative data analysis in one production cycle. The first objective is achieved by describing the profile and general description of the brown sugar processing and the brown sugar production process. The second objective is achieved by determining the added value through Hayami Method [6]. The Hayami method was selected for its better application in a series of related industries in the supply chain, easy to be implemented and provided complete information to the actors and the laborers.

\section{Results and Discussion}

\subsection{Sugarcane Production Process into Brown Sugar}

Brown sugar (also called saka) produced in Bukik Batabuah Village is categorized into 2 kinds: saka gatah and saka kariang. Saka gatah is further divided into saka gatah merah and saka gatah kuniang, while saka kariang is also called saka putiah. The production process of the three types of brown sugar is almost alike, and the only factor distinguishing them is the time of molding. After boiled, saka kariang must be molded immediately, while in producing saka gatah, its tengguli (boiled neera or sugarcane juice) should be stored for 7 days before it is molded.

Based on the results of this research, it can be concluded that the three types of brown sugar have some differences in terms of production process, characteristics, and price. In terms of production, the only difference found is the time needed in boiling process, tengguli storage and tengguli heating in the production process of saka gatah. In terms of characteristics, the three types of brown sugar nearly have similar taste, but there is a difference in their texture, saka kariang is classified as dry brown sugar, while saka gatah belongs to wet and sticky brown sugar.

The color of the three types of brown sugar is also different. The color of saka kariang is light brown, saka gatah merah is dark brown and saka gatah kuniang is brownish yellow. In addition, 
there is also a difference in terms of price, while the selling price of saka kariang and saka gatah merah is IDR 9,000 per kilogram, the selling price of saka gatah kuniang is IDR 10,500 per kilogram.

\subsection{The Analysis of the Added Value to Brown Sugar}

The calculation of the added value is based on the amount of the raw material, i.e. sugarcane. The average input of raw material used in one cycle of production of saka kariang is 202.38 kilogram of sugarcane, saka gatah merah is 3,003 kilogram of sugarcane and saka gatah kuniang is 2,755 kilogram of sugarcane. The variation in the amount of sugarcane used depends on the size of the sugarcane stalk as well as the quantity of juice produced from one sugarcane stalk.

The output from the processing of sugarcane is brown sugar. In the added value calculation, the output of brown sugar is measured in kilograms to obtain its conversion factor value. The average output of saka kariang produced by the farmers in one production process is 17.87 kilogram, saka gatah merah is produced on the average of 214.25 kilograms per production process, while saka gatah kuniang is produced on the average of 215 kilograms per production process.

The conversion factor is the ratio between the amount of brown sugar produced and the amount of sugarcane used in one production process. The conversion factor of saka kariang production is 0.09 , meaning that every kilogram of processed sugarcane produces 0.09 kilograms of saka kariang. The conversion factor of saka gatah merah is 0.07 , meaning that every kilogram of processed sugarcane produces 0.07 kilograms of saka gatah merah. The conversion factor of saka gatah kuniang is 0.08 , meaning that every kilogram of processed sugarcane produces 0.08 kilograms of saka gatah kuniang. The score of the conversion factor is influenced by the amount of brown sugar produced, the amount of sugarcane raw materials used and the rendemen of sugarcane.

The number of paid labors employed in processing saka kariang, saka gatah merah and saka gatah kuniang is 1 person each. These labors are assigned to harvest and carry sugarcane from the sugarcane field to the sugarcane mill by shoulder. The number of working days is 4 days a month, while the working time is 8 hours per day.

Brown sugar agroindustry employs more family labors in its production activities. On average each of sugarcane mill employs 2 family labors comprising 1 male and 1 female labors. Female labor is responsible of sugarcane cleaning, nira cooking and brown sugar packing, while male labor is responsible of sugarcane milling and tenuli molding. In the production of saka kariang, the family labors work 8 days a month; on the contrary, the family labors in saka gatah processing work 10 to 12 days a month. This difference is caused by the time spent in saka gatah processing taking 7 days for sugarcane milling and nira cooking, and 3 to 5 days for tenuli heating and tenuli molding before it turns into brown sugar. Meanwhile, the production activities of saka kariang involve only 2 days in a week, i.e. Sunday and Monday. Within one 
day, the family labors work for 10 hours, meaning that in one production process, the labors within the family work for 5 hours.

The paid labors for one cycle of saka kariang production process is 0.5 man-days per production, while saka gatah merah and saka gatah kuniang needs 4 man-days per production. Family labors for one cycle of saka kariang production process is 0.5 man-days per production for female labors and 0.625 man-days per production for male labors. Meanwhile, the family labors for one cycle of saka gatah merah and saka gatah kuniang production process is 10 man-days per production for female labors and 12.5 man-days per production for male labors.

The coefficient of family labors in the saka kariang processing is 0.0056 , meaning that the processing of a kilogram of sugarcane needs 0.0056 man-days, while the coefficient of paid labors in the saka kariang processing is 0.0024 , meaning that carrying a kilogram of sugarcane needs 0.0024 man-days. The coefficient of family labors in the saka gatah merah processing is 0.0075 , meaning that the processing of a kilogram of sugarcane needs 0.0075 man-days, while the coefficient of paid labors in the saka gatah merah processing is 0.0013 , meaning that carrying a kilogram of sugarcane needs 0.0013 man-days. The coefficient of family labors in the saka gatah kuniang processing is 0.0082 , meaning that the processing of a kilogram of sugarcane needs 0.0082 man-days, while the coefficient of paid labors in the saka gatah kuniang processing is 0.0015 , meaning that carrying a kilogram of sugarcane needs 0.0015 man-days.

The calculation of the labor coefficient indicates that the process of saka gatah kuniang production takes longer time than does the process of saka kariang and saka gatah merah production. This is influenced by the length of time needed to heat the tenuli of saka gatah kuniang before being molded. Heating 5.4 liters of tenuli of saka gatah kuniang needs 30 minutes; in contrast, with the same amount of time, 10.8 liters of tenuli of saka gatah merah can be heated.

The average value of saka kariang is IDR $810 / \mathrm{kg}$, meaning that every kilogram of sugarcane produces saka kariang worth IDR 810. The average value of saka gatah merah is IDR 630/kg, meaning that every kilogram of sugarcane produces saka gatah merah worth IDR 630. The average value of saka gatah kuniang is IDR $840 / \mathrm{kg}$, meaning that every kilogram of sugarcane produces saka gatah kuniang worth IDR 840. The factors that influence the value of brown sugar are the value of conversion factor and the price of the brown sugar itself.

The added value resulting from the processing of sugarcane into saka kariang is IDR 165.34/ $\mathrm{kg}$, meaning that every kilogram of saka kariang has the added value of IDR 165.34. The added value resulting from the processing of sugarcane into saka gatah merah is IDR $20.87 / \mathrm{kg}$, meaning that every kilogram of saka gatah merah has the added value of IDR 20.87. The added value resulting from the processing of sugarcane into saka gatah kuniang is IDR 131.81/kg, 
meaning that every kilogram of saka gatah kuniang has the added value of IDR 131.81. The added value ratio is calculated by dividing the added value (IDR/kilogram) with the output value (IDR/ kilogram) and multiplying by 100 percent. The added value ratios of saka kariang, saka gatah merah, and saka gatah kuniang are 20.41 percent, 3.31 percent and 15.69 percent, respectively.

In the production of saka kariang, the benefit of paid and family labors is IDR $0.36 / \mathrm{kg}$ and IDR $1.52 / \mathrm{kg}$ respectively. In the process of saka gatah merah production, the benefit received by the paid and family labors is IDR $0.10 / \mathrm{kg}$ and IDR $2.75 / \mathrm{kg}$ respectively. In the process of saka gatah kuniang production, the benefit received by the paid and family labors is IDR $0.13 / \mathrm{kg}$ and IDR $3.27 / \mathrm{kg}$ respectively.

The benefit amount received by the labors is influenced by the coefficient value of labor and the average wage of labor. In Bukit Batabuah Village, the average wage of male and female labors is IDR 60,000/working day and IDR 50,000/working day respectively. As a result, the factor distinguishing the benefit/income between the labors in processing the 3 types of brown sugar is the coefficient value of labor.

The percentage of share received by the paid labors in the process of saka kariang, saka gatah merah, and saka gatah kuniang production is 0.22 percent, 0.48 percent and 0.09 percent, respectively. Meanwhile, the percentage of benefits received by the family labors in the process of saka kariang, saka gatah merah, and saka gatah kuniang production is 0.92 percent, 13.18 percent and 2.48 percent, respectively. The profit received by the farmers of saka kariang, saka gatah merah, and saka gatah kuniang processing is the difference between the added value and the labor's benefits. The profit received by the farmers of saka kariang is IDR 163.46 per kilogram of sugarcane with a profit rate of 20.18 percent. The profit received by the farmers of saka gatah merah is IDR 18.02 per kilogram of sugarcane with a profit rate of 2.86 percent. Meanwhile, the profit received by the farmers of saka gatah kuniang is IDR 128.41 per kilogram of sugarcane with a profit rate of 15.29 percent. The farmers of saka kariang receive the biggest profit, followed by the farmers of saka gatah kuniang and the farmers of saka gatah merah. The amount of the profits received by the brown sugar farmers is influenced by the amount of generated added value and the amount of benefits received by the labors.

The findings show that the brown sugar farmers can produce the added value per kilogram of saka kariang at 20.41 percent, the added value per kilogram of saka gatah kuniang at 15.69 percent, and the added value per kilogram of saka gatah merah at 3.31 percent, which is the smallest added value per kilogram of brown sugar processing. After doing the added value calculation, added value testing can be done following the Hubeis' testing criteria in Santoso et al. [7] based on which it can be concluded that the added value in the agroindustry of saka kariang and saka gatah kuniang has a medium added value ratio. Meanwhile, saka gatah merah 
is a product with a low added value ratio. The result also find that added value was distributed to paid and family labors, as well as to other input contributors.

The margin value obtained in the processing of saka kariang is IDR 324.52/ $\mathrm{kg}$ of sugarcane. The proportion of the largest margin distribution was obtained by the farmers who gain 50.37 percent of the profit and other input contributors at 49.05 percent of the profit. The distribution to the labors is the smallest part when compared with the share for the farmers and other input contributors. The margin received by the labors consists of the remuneration of the factor of production of labors outside the family labor who gain 0.11 percent and labors in the family who gain 0.47 percent of the profit. This indicates that the proportion of the smallest distribution is received by the labors outside the family.

The margin value of saka gatah merah processing is IDR $170.13 / \mathrm{kg}$ of sugarcane. The actors that receive the largest margin distribution are the other input contributors, at the cost of the auxiliary materials reaching 87.73 percent. On the other hand, the labors in this processing are the actors that receive the smallest margin distribution. The margins distributed to the labors consist of 0.06 percent to the labors outside the family and 7.75 percent to the labors in the family. This indicates that the proportion received by the labors in the family is the smallest proportion.

In the processing of saka gatah kuniang, the margin value obtained is IDR 319.13/ kg of sugarcane. Similarly, in the processing of saka kariang and saka gatah merah, the smallest distribution proportion is received by the labors. The margins distributed to the labors consisted of 0.04 percent of the labors outside the family and 1.02 percent of the labors in the family. This shows that the smallest proportion is received by the labors outside the family. Meanwhile, the largest margin distribution proportion is received by the other input contributors, i.e. the cost of auxiliary materials reaching 58.70 percent.

In this case, it can be concluded that the paid labor gets the smallest added value distribution proportion. The paid labor plays a role in the distribution of key raw materials in the activities of brown sugar processing, while the family labor who is also a brown sugar producer gets a substantial proportion of profit from the generated added value.

The added value distribution is closely related to the technology applied during the processing, the quality of labors and the raw materials. When labor-intensive technology is chosen, the proportion for the labor share is greater than the proportion of the profit of the brown sugar farmers and vice versa if capital-intensive technology is chosen (Sudiyono, 2004).

Viewed from the business revenue side, the revenue from the processing of saka kariang per one production cycle is on the average of IDR 160,830. Meanwhile, the average production cost that must be spent for every production cycle is IDR 207,841.48, including the cost of raw 
materials, the wage of labors in the family and the cost of unpaid depreciation. The revenue from the processing of saka gatah merah and saka gatah kuniang per one production cycle is on the average of IDR 1,928,250 and IDR 2,257,500. Meanwhile, the average production cost that must be spent for every production cycle of saka gatah merah and saka gatah kuniang is IDR $2,774,593.36$ and IDR 3,485,215.48, including the cost of raw materials, the wage of labors in the family and the cost of unpaid depreciation.

Finally, the finding concludes that economically, sugar processing business does not provide profits for the brown sugar producers because the profits received largely derived from the wage of family labors, the cost of sugarcane raw materials and the cost of unpaid depreciation. This is similar with Supriyati [3] study that shows the laborers in household handicraft industry is dominated by family laborers, so the consequence is that the family labors do not earn income, and in the HHI output value, their payment is called benefits for labors. So the added value of rural agroindustry is mostly wage of the family labors family.

\section{Conclusion and Recommendation}

\subsection{Conclusion}

The processing of the three types of brown sugar, saka kariang, saka gatah merah and saka gatah kuniang almost similar as the only difference lies on the time needed in boiling process, tengguli storage and tengguli heating in the production process of saka gatah. In addition, these three types of brown sugar have different characteristics in terms of texture, taste and color.

Saka kariang and saka gatah kuniang belong to the brown sugar products with a medium added value ratio, while saka gatah merah is a product with a low added value ratio. The actors with the smallest added value distribution proportion is the labors outside the family, while the labors in the family who are also the brown sugar producers get a substantial proportion of profit from the generated added value. However, the profits received largely come from the wage of labors in the family, the cost of sugarcane raw materials and the cost of unpaid depreciation.

\subsection{Recommendation}

The findings suggest to focus on business development of processing saka kariang because it produces higher added value than another kind of brown sugar, saka gatah. The added value of brown sugar can be enhanced by the use of effective and efficient production equipment or machinery, so that the added value distributed to the brown sugar agroindustry can be improved. 


\section{REFERENCES}

[1] M. Kuncoro, Ekonomika Pembangunan: Masalah, Kebijakan, dan Politik. Jakarta: Erlangga, 2010.

[2] I. G. B. Udayana, "Peran agroindustri dalam pembangunan pertanian," Singhadwala, vol. 44, pp. 3-8, 2011.

[3] Supriyati, Peranan Agroindustri Pedesaan dalam Perekonomian dan Perspektif Pengembangannya. Bogor: Pusat Analisis Sosial Ekonomi dan Kebijakan Pertanian, 2007.

[4] S. Hidayat, Marimin, A. Suryani, Sukardi, and M. Yani, "Model identifikasi risiko dan strategi peningkatan nilai tambah pada rantai pasok kelapa sawit," Jurnal Teknik Industri, vol. 14, no. 2, pp. 89-96, 2012.

[5] Nusyirwan, "Kajian proses pembuatan gula merah di Lawang Kabupaten Aga," Laboratorium Konstruksi dan Perancangan Mesin, vol. 28, no. 1, pp. 108-110, 2007.

[6] Y. Hayami, et al., Agricultural marketing and processing in upland java, a prespective from Sinda Village. Bogor: Coarse Grains Pulses Roots and Tuber Center (CGPRTC), 1987

[7] H. Santoso, R. Hartono, and S. L. Savitri, "Potensi agroindustri berdasarkan kinerja usaha dan strategi pengembangannya," Agricultural Socio-Economics Journal, vol. 10, no. 3, pp. 177-190, 2010. 